\title{
Operation of Higher Education Institution-Based Cooperatives in Nueva Ecija
}

\author{
Rollieza Grace M. Daus-Taruc
}

\begin{abstract}
This study evaluated the operation of Higher Education Institution (HEI)-based cooperatives in Nueva Ecija. It described the cooperatives' historical antecedents and different aspects of operation in terms of organization and management, market and marketing,
\end{abstract} production/technical and financial aspects. The study also identified the challenges and problems encountered by the cooperatives. The study employed the descriptive type of research and the respondents of the study were the general managers and members from two public and two private HEIs in Nueva Ecija. The result of the study revealed that HEI-based cooperatives are classified as credit, multipurpose, consumer and housing cooperatives, all operating for more than two decades. All of the cooperatives have the same set of key officers who managed the operation of the organization. They used fliers, social media and public announcement to disseminate information. The cooperatives primarily offered cash loans and selling of various commodities. As to fund resources, cooperatives sourced out their fund through the share of a capital subscription among the members. Top problems encountered by the cooperatives include limited membership expansion, decreased volume of sales, difficulties in marketing loan packages to faculty members with high take-home pay, time management and availability of officers and slow retrieval of land titles from National Housing Authority (NHA).

Recommendations offered to improve the operation of cooperatives are continuous enhancement of their operation through the integration of technology, additional personnel, new services and crafting new policies that will benefit more members of the cooperatives.

Keywords- Cooperatives, financial, management, marketing, organization, operation \& technical.

\section{INTRODUCTION}

Different financial institutions offer a financial solution to the less fortunate segments of the society and cooperative is one of the many that gives a lower cost of financing. Putting up a cooperative in a particular agency, unit or institution of the community has become a dominant feature of poverty alleviation program implemented by the organization. By making reserve funds, these cooperatives help to lessen members' burden in searching for immediate cash assistance for the unforeseen expenditures. Benefits gained from cooperatives create an impact on the economic conditions of members [1]. Aside from the financial assistance during the recession period, the decrease in financial suffering due to significant debts can lessen the negative impact on health conditions of the members.

According to [2], "cooperatives are autonomous associations of persons united voluntarily to meet their common economic, social and cultural needs and aspirations through a jointly owned and democratically controlled enterprise." Likewise, [3] stated that"cooperatives have been considered the key and strategy for development, specifically rural development. While [4]said, a co-op is a better co-op when it effectively meets the needs of its members. Cooperatives are good at delivering benefit to members in part because they are so flexible. A co-op does not have to have a complicated system of equity allocation and distribution to meet the needs of its membership, but the ability to tailor important elements of the ownership structure for the good of the membership is one of the things that help co-ops to serve their members well. Thus, [5] mentioned that cooperatives should provide quality supplies and services to its members at a reasonable cost.

Additionally, [6] states that the business philosophy of cooperatives is based on the concept of enlightened self-interest, which is expressed from the standpoint of the cooperating members. Furthermore, he emphasized the value of education as one of the important principles to foster the cooperative spirit. Though members do not have to handle the daily management of the cooperative, they must not completely rely on the managers because this could be a source of mismanagement, graft and corruption. Members must be knowledgeable enough about the operation of their cooperative to achieve check and balance and this knowledge can be acquired through education.

In general, there are different kinds of cooperatives, namely: (1) Credit Cooperative, which 
promotes thrift and savings among its members and creates funds in order to grant loans and productivity; (2) Consumer Cooperative, the primary purpose of which is to procure and distribute commodities to members and non-members; (3) Producers Cooperative, which undertakes joint production whether agricultural or industrial; (4)Marketing Cooperative, which engages in the supply of production inputs to members and markets their products, (5) Service Cooperative, which engages in medical and dental care, hospitalization, transportation, insurance, housing, labor, electric light and power, communication and other services; and (6) Multipurpose Cooperative, which combines two or more of the business activities of these different types of cooperatives [7].

The need to establish a cooperative in schools is imperative for it is a great help in augmenting the meager income of its employees and teachers. Teachers and staff may derive their income different from one another and income serves as the basis for individual expenditures. Despite the regular or monthly salary that employees receive, most of them have additional financial resources to cover ordinary living expenses, raise and improve household welfare, academic support, and unexpected emergencies. Cognizant of the financial needs of the employees in the academe, Higher Education Institution (HEI) have engaged in the establishment of cooperatives to encourage thrift and savings mobilization among members for capital formation.

Based on the [8], it is a general observation that in Nueva Ecija,most if not all educational institutions operate an institutional cooperative, and they are operating in consonance with the Cooperative Code of the Philippines.

Studies about cooperatives are confined mostly on tackling operations and management of privately-owned cooperatives or those that were organized by laborers, and industrial and agricultural sectors. Meanwhile, there were a few types of research on assessing and evaluating educational institution-based cooperatives. With the engagement of HEIs in operating cooperatives and to fill the gap on academic-based researches focusing on HEI-based cooperatives, it is but timely and relevant to conduct this study focusing on the operation of this type of cooperative.

The researcher being a member of an academic institution aimed to assess the current status of the so-called School-based Institutional Cooperatives in Nueva Ecija which are focused on operation on the following aspects: organization and management, market and marketing as pect, production/technical aspect and financial aspect.
The researcher further delved on the impact of the cooperatives on their members and the academic institutions in general. It is hoped that this research will be beneficial to the members for it will serve as an avenue to identify the problems encountered by the members and by the management of Higher Education Institution (HEI)-based cooperatives. With the result of this study, a development plan was formulated to enhance the services of the existing cooperatives to better serve their members

Furthermore, the conduct of this study could influence other academic institutions, be it a private or state university to take initiatives on establishing cooperatives that could extend support to their personnel in terms of financial assistance.

\section{METHODOLOGY}

The study employed a descriptive type of research. Descriptive research according to [9] as cited by the authors in [10], systematically describes a situation, problem, phenomenon, service or program, attitude towards an issue or simply, it provides information on a subject. In particular, the study described the historical antecedent of the cooperatives in terms of their type, years of existence, membership, and services offered. Cooperatives, as a business enterprise, were also analyzed based on organization and management, technical/production, and financial aspects. The services offered enjoyed by the members and the problems encountered by the cooperatives are also included. The results of analyzes were the basis in the preparation of a strategic development agenda on the operation of cooperatives in HEIs.

The study was conducted in two public and two private Higher Education Institutions (HEIs) in Nueva Ecija. A total of 70 purposively chosen people served as respondents of this study. They were chosen purposively based on the following criteria [11]: they are members of the institutional cooperatives in and are more than five years as members of the cooperatives. Complete enumeration was utilized in choosing additional respondents of this research. They are allsix (6) General Managers of the cooperativerespondents

The questionnaire for the general managers of the cooperatives was used to gather data on the cooperative's historical antecedent, business operation, and challenges and problems faced in operation. The questionnaire for members gathered data on membership, services offered, and problems faced in the operation of the cooperative. 
Frequency and percentage were the statistical tools utilized to present the numerical data gathered.

\section{RESULTS AND DISCUSSION}

1. Describe the Historical Antecedents of HEI-Based Cooperatives in Nueva Ecija on the following aspects:

\subsection{Type of cooperative}

The classification of the HEI-based Cooperatives in Nueva Ecija are Credit Cooperative (.33\%), Multipurpose Cooperative (.33\%), Consumer Cooperative $.17 \%$ and Housing Cooperative $(.17 \%)$.

\subsection{Years of existence}

From the six cooperative-respondents, three of them were established for more than two decades. One has been operating for three decades and two for more than half of a century.

\subsection{Membership}

Membership of cooperatives was classified as regular members and associate members. Fifty $(50 \%)$ of the HEI-based Cooperatives in Nueva Ecija are composed of regular members where the majority of them were female teaching personnel. The remaining fifty $(50 \%)$ has a composition of regular and associate members, almost $10 \%$ of the total population were associate members where the majority of them belong to the non-teaching personnel of the University.

\subsection{Services offered}

Majority of the HEI-based Cooperatives in Nueva Ecija offer cash loan (67\%), selling of commodities $(.33 \%)$ which can be on a cash basis or credit and housing loan (.17\%).

\subsection{Mandatory pieces of training attended.}

Mandatory training for cooperative officers is a training requirement that all officials of the organization must comply. All of the HEIbased Cooperatives in Nueva Ecija attended mandatory training required by the CDA. Training that they attended are Fundamentals of Cooperatives, Basic Cooperative and Good Governance Management, Basic Principles of
Sustainability, Financial Management, Risk and Credit Management and others.

\section{Describe the Operation of HEI-Based Cooperatives in Nueva Ecija}

\subsection{Organization and Management}

All of the cooperatives under survey have the same set of key officers. They all composed the Board of Directors, Managers and Bookkeepers. Cooperatives 1, 3, 5 and 6 vary in some supporting staff like some have additional clerks to look into loans, office clerks, treasurer and secretary to do the operation. Cooperatives 2 and 4, which offer cooked foods, groceries and other dry goods hire cook, sales staff, merchandiser and cashier who assist the officers to supervise the organization and the operation.

All of the key officers like members of the Board of Directors and Managers receive honoraria while clerical jobs are performed by the hired personnel that receive a standard salary prevailing within the locality and they also receive other benefits .

\subsection{Market and Marketing}

Majority of the HEI-based Cooperatives in Nueva Ecija took advantage of the marketing opportunity during meetings and general assembly. Distribution of fliers, the use social media, public announcement through posting of banners and streamers in strategic places such as in the school premises are some of the effective tools they have been using for information dissemination.

Recruitment and retention of members and non-members are important for the sustainability of the existing cooperative. All of the cooperative-respondents have been applying the same techniques, like offering a lower rate of interest compared to any other financial institutions and faster processing time for loan application. They also increase the amount of loan if the borrower-member applied for a larger amount, provided that as per evaluation, a member's capacity to pay will be the foremost requirement for approval. The management also gives freebies and other giveaways during Christmas to the members. 


\subsection{Production/Technical Aspect}

\subsubsection{Production/Technical Aspect}

Most of the services offered by the HEIbased Cooperatives in Nueva Ecija to its members were cash loan, selling of school supplies, cooked food and other grocery items and housing loan.

Interest rates are lower than other financial institution and amortization is paid through payroll deduction or over the counter of the cooperative office. Renewal of loan is granted if they have settled at least $50 \%$ to $70 \%$ of the loan term with a $3 \%$ penalty of the remaining balance if member-borrower fails to settle obligations.

\subsubsection{Logistical Support}

Majority of the cooperatives under survey occupy an office space where business activities take place. Most of the offices they occupy are with air conditioning unit. Office machines, equipment and devices are all available and functional. Basic facilities such as comfort room, receiving room/area and others are all available to most of the Cooperatives.

\subsection{Financial Aspect}

The financial aspect is described in terms of the income of the cooperatives, its capital buildup strategies and its collecting rate.

\subsubsection{Cooperatives Capitalization}

Greater percentage of the HEIbased Cooperatives in Nueva Ecija have a capital ranging from $\mathrm{P5}, 000,001$ to $\mathrm{P} 10,000,000 \quad(33 \%), 17 \%$ ranges from $\mathrm{P} 25,000,001$ to $\mathrm{P} 30,000,000$. $17 \%$ have a capital ranging from $\mathrm{P} 15,000,001$ to $\mathrm{P} 20,000,00,17 \%$ fall under the bracket of $\mathrm{P} 1,000,001$ to $\mathrm{P} 5,000,000$ and $17 \%$ is less than a million pesos.

\subsubsection{Capital Build-up and Collection}

rate.

Greater percentage of the
Cooperatives under survey have a
minimum capital subscription of
P15,000.00 $\quad(33 \%), \quad$ issuance of

authorization to deduct a certain amount from the member's monthly salary as per his prerogative relative to his/her share capital (33\%); subscription of at least 200 shares for a total of P20,000.00 (17\%) and a minimum of $\mathrm{P} 10,000$ share capital $(17 \%)$.

\subsubsection{Income of the Cooperative}

Majority of the total income computed is increasing yearly. However, there was a sudden decrease in income for some years but eventually recovered in the later years. From the two cooperatives, income recorded for 1 Cooperative has been fluctuating for more than a decade and the other one has a deficit for two consecutive years.

3. Challenges and Problems Encountered in the Operation of the Cooperatives

\subsection{Organization and Management}

The HEI-based Cooperatives in Nueva Ecija has a slow rate in membership expansion.

\subsection{Market and marketing}

HEI-based Cooperatives in Nueva Ecija that offer tangible products need a strategic campaign to increase the volume of sales. Existence of other competitors inside and outside the school premises affects the sales.

Cooperatives that offer cash loan encounter difficulties in marketing loan packages to faculty members with high take-home pay.

The "wait and see attitude," where the member remains unrealized until loan application of other members has been approved.

\subsection{Production/Technical Aspect}

Time management and unavailability of officers with direct contact to the borrower-members due to the positions or designation they handle in their respective academic institutions. 
Slow retrieval of land titles from the National Housing Authority (NHA).

A more spacious work place for cooperatives that offer commodities is needed to avoid shoplifting and miscommunication with the buyers/borrowers and sellers. The terms and condition and the quality of the products from the suppliers must be put into considerations.

\subsection{Financial Aspect}

Collection of outstanding overdue accounts; request for an additional amount of loan even the combined monthly amortization has exceeded to its limit of P5,000 net takehome pay; slow retrieval of titles from National Housing Authority (NHA); and withdrawals of membership and its equivalent capital share affects income generation.

\section{Proposed Development Agenda for the Operation of Cooperatives}

a. Conduct of campaign to disseminate information about the features of the HEI-based cooperative.

b. Hire additional personnel and work full-time to deliver effective and efficient services to every member.

c. Revision of the loan policy to accommodate new lending activity without a major renovation.

d. Marketing through the use of promotional techniques to help understand what the product or service of the cooperative can offer and how to plan for a successful product offering.

e. Request for bigger office space from the University.

f. Computerization of cooperatives' operations.

g. Provision of additional benefits of cooperative members

\section{CONCLUSIONS}

Based on the findings, the following conclusions are drawn:

1. The classification of the HEI-based Cooperatives in Nueva Ecija are Credit Cooperative, Multipurpose Cooperative, Consumer Cooperative and Housing Cooperative. They were established for more than two decades. Majority of the Cooperatives were composed of regular members where a greater percentage of them were female teaching personnel. All of the Cooperative officers attended mandatory pieces of training required by the CDA. Training that they attended are Fundamentals of Cooperatives, Basic Cooperative and Good Governance Management, Basic Principles of Sustainability, Financial Management, Risk and Credit Management and others.

2. All of the cooperatives under survey have the same set of key officers. They all composed the Board of Directors, Managers and Bookkeepers. They vary in some supporting staff like clerks to look into loans, office clerk, treasurer, cook, sales staff and others. All of the key officers like Board of Directors and Managers receive honoraria while other supporting personnel/staff receive a salary and other benefits. They use fliers, social media, public announcement through the posting of banners and streamers in strategic places in the school premises as an effective tool for information dissemination. They offer cash loan, selling of school supplies, cooked food and other grocery items and housing loan with low interest. Majority of the cooperatives under survey occupy office space with proper ventilation. Their fund resources come from a shared capital subscription where the majority of the total income computed is increasing yearly.

3. Top problems of HEI-based cooperatives in Nueva Ecija were: slow increase in membership; decrease the volume of sales; existence of other competitors inside and outside the school premises; difficulties in marketing loan packages to faculty members with high take-home pay; time management and availability of officers; slow retrieval of land titles from National Housing Authority (NHA); more spacious work place for cooperatives that offer commodities; the terms and condition and the quality of the product from the suppliers; and withdrawals of membership and its equivalent capital share.

4. The stability and competitiveness of the HEI-based cooperatives in Nueva Ecija will be realized through the collective effort of the cooperative 
management and the academic institutions where they belong.

\section{RECOMMENDATIONS}

Based on the above findings and conclusions, the following recommendations are made:

1. Annual general assembly meeting should be considered to increase members' awareness about products and services of the cooperative. Hence, the number of members will increase.

2. Continually provide demand-driven services to create more opportunities for the members of the cooperatives.

3. Review of credit policy should be considered to update the organization from the most effective rules and policy that can be applied.

4. Annual accomplishment reports must be presented to the members of the cooperatives for transparency.

5. Encourage members and non-members to patronize cooperatives' products and services to realize more income.

6. Provide other forms of assistance for members such as mutual aid, death aid and medical assistance which will be granted to all members for free may be considered.

7. Part of mandatory savings of cooperative for community development must be used for projects intended for the benefit of HEIs.

8. HEI Cooperatives must endeavor to organize, assist students in creating Laboratory Cooperative.

\section{REFERENCES}

[1] Matchboxflores. Cooperative in the Philippines.https://www.termpaperwarehouse.com/ess ay-on/Cooperative-In-The-Philippines/80928

[2] UNDESA-United Nation Department of Economics and Social Affairs (2012) Promoting Productive Capacity for Sustainable Livelihoods: The Role of Cooperatives. Retrieved from https://www.un.org/development/desa/cooperatives/w hat-we-do/55-2.html

[3] Mendoza, I (2016) THE ROLE OF COOPERATIVES IN EMPOWERING INDIGENOUS PEOPLE AND OLDER PERSONS. Retrieved fromhttp://www.un.org/esa/socdev/egms/docs/2016/C oops-2030Agenda/Mendoza.pdf
[4] Zimbelman, K., et.al. (1999).Building and Improving Membership Programs. Retrieved from https://www.grocer.coop/articles/building-andimproving-membership-programs

[5] Mullinnix, J (2016)The Value Of Cooperatives In Modern Agriculture. Retrieved from http://www.croplife.com/management/the-value-ofcooperatives-in-modern-ag ricu ltu re/

[6] Deriada, A.L.(2005). Assessment of Cooperative Movement in a Developing Country: The Philippine Experience. Retrieved from https://www.gsid.nagoyau.ac.jp/bpub/research/public/forum/28/04.pdf

[7] Fred, A. (2009). Cooperatives, Corporate and Investments, Philippine E-Legal Forum. Retrieved from.https://jlp-law.com/blog/author/fred/page/4/

[8] Cooperative Development Authority (CDA)2015 Summary Report of Registered Cooperative in Region III

[9] Kumar, R. (2014). Research methodology: A stepbystep guide for beginners (4th ed.) SAGE. CA:Thousand Oaks

[10] Gener S. Subia, Cherrylyn L.Trinidad, Rodelio R. Pascual, Hernina B. Medrano \& Eminiano P. Manuzon.Learning Styles and Preferred Teaching Styles of Master of Arts in Teaching (MAT), major in Vocational Technological Education (VTE) Generation Y Learners. International Journal of English Literature and Social Sciences (IJELS) Vol-4, Issue-2, Mar - $\quad$ Apr, 2019.https ://dx.doi.org/10.22161/ijels.4.2.35.

[11] Subia, G.S. (2018). Comprehensible Technique in Solving Consecutive Number Problems in Algebra. Journal of Applied Mathematics and Physics, 6,447457. https://doi.org/10.4236/jamp.2018.63041 